\author{
В. Луцков,
}

аспірант кафедри конституційного права

Національного університету «Одеська юридична академія»

\title{
ПРОТЕСТНИЙ ПЕРФОРМАНС ЯК ФОРМА БЕЗПОСЕРЕДНЬОЇ УЧАСТІ ЧЛЕНІВ ТЕРИТОРІАЛЬНОЇ ГРОМАДИ У ЗДІЙСНЕННІ МІСЦЕВОГО САМОВРЯДУВАННЯ
}

\begin{abstract}
Актуальність теми дослідження. Форми безпосередньої участі членів територіальної громади у здійсненні місцевого самоврядування - одне з найважливіших питань, від вирішення яких залежить розвиток населених пунктів. Окремі форми з'явились сотні років тому і вже встигли стати «класикою» для багатьох територіальних громад у всьому світі. Проте в наш час з'являються нові інструменти для безпосередньої участі членів територіальної громади, що можуть конкурувати в ефективності зі звичними формами. Такою новаційною формою безпосередньої участі членів територіальної громади у здійсненні місцевого самоврядування $€$ перформанс, який наразі все частіше проявляє себе як нестандартна протестна форма безпосередньої участі членів територіальної громади у здійсненні місцевого самоврядування.

Перформанс був предметом дослідження вчених-культурологів К.О. Бобринської, Ю.В. Кривцової [1], Роузлі Голдберг (Roselee Goldberg) [2], Марвіна Карлсона (Marvin Carlson) та інших. У правовій науці перформанси та протестні перформанси не розглядались ні в аспекті місцевого самоврядування, ні в аспектах публічного адміністрування.
\end{abstract}

Метою статті $€$ аналіз протестного перформансу як складової частини відносин місцевого самоврядування; розгляд перспектив його застосування територіальною громадою для участі у вирішенні питань місцевого значення.

Завданнями роботи $€$ виокремлення ознак перформансу (в тому числі протестного перформансу) як мистецько-культурного явища; виявлення спільних та відмінних рис протестного перформансу та найбільш врегульованих вітчизняним правом протестних форм безпосередньої участі членів територіальної громади у здійсненні місцевого самоврядування (мітинги, демонстрації, страйки); аналіз позитивних та негативних сторін протестного перформансу як форми безпосередньої участі членів територіальної громади у здійсненні місцевого самоврядування; надання рекомендацій щодо нормативно-правового регулювання протестного перформансу в Україні.

Поняття перформансу належить до сфери мистецтва [1]. Зокрема, відповідно до Сучасної енциклопедії перформанс - система дій виконавця або виконавців, розрахована на публічну демонстрацію (наприклад, створення твору мистецтва або іншої дії, зазвичай абсурдистського напрямку) [3]. Одним із найбільш усесвітньо відомих відомих перформансів стало «Балканське Бароко» 1997 року. Суть перформансу полягала в тому, що творець, громадянка Сербії Марина Абрамович, по декілька годин в день відмивала кістки 


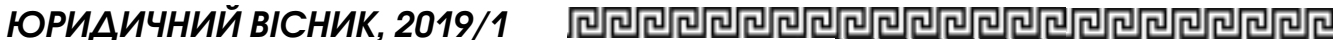

від крові. За поясненнями митця, ці дії відсилались до загибелі людей під час військових дій в Югославії [4]. Без пояснень авторки такі дії дійсно могли б видатись б абсурдними, але завдяки інтерпретації творця вони набувають символічного значення та привертають увагу до певної проблеми.

Через те, що перформанс результат творчості, в нього завжди $€$ творець, що в абсолютній більшості випадків не приховує своєї персони (здебільшого він же і виконавець). Улай, Марина Абрамович, Петро Павеленський - всесвітньо відомі художники, імена яких стали відомими саме завдяки перформансам і які на них спеціалізуються. Професійних перформансистів ще також називають художниками-акціоністами [5-7].

Іншим важливим суб'єктом у перформансі $€$ «публіка». «Публікою», тобто цільовою аудиторією перформансів, можуть бути: суспільство всередині краіни (в тому числі територіальні громади), людство в цілому, влада (загальнодержавна та/або місцева), міжнародна спільнота, окремі фізичні або юридичні особи. Окремо варто відзначити особливу роль засобів масової інформації, які виступають «посередниками» в донесенні мети, та значення перформансів не лише для цільової аудиторії, але й для всіх інших суб'єктів, що можуть бути цільовою аудиторією.

Перформанси, так само як i iнші твори мистецтва, є унікальними і зазвичай проводяться одноразово. Більшість перформансів також мають власні імена: «Балканське бароко» [4], «Трава пробиває землю» [8] тощо.

Творчий характер у контексті перформансів означає нетривіальний підхід у донесенні певної ідеї до цільової аудиторії: використання художніх метафор, порівнянь i т.д. Тому для непідготованої публіки без пояснень автора перформанс може не проявляти конкретної закладеної ідеї. Саме тому такими важливими в багатьох перформансах є пояснення творця, які розкривають контекст дій, що здійснювалися в перформансі.
Наявність таких ознак підтверджує й аналіз інформаційних ресурсів із розкритим змістом найвідоміших перформансів. Можна зробити висновок, що ознаками перформансу є: наявність персоніфікованого автора (авторів), з однієї сторони, та «публіки», з іншої сторони; разовий, унікальний характер реалізації; творчий підхід до створення перформансу; необхідність пояснення змісту перформансу автором (митцем) [2-7].

Разом із тим перформанс може мати правову природу, а особливо часто пов'язаний із конституційними правовідносинами. Так, варто продемонструвати прояви перформансу в різних елементах конституційно-правових відносин.

На думку В.Л. Федоренка, об’єктом конституційних правовідносин виступають головним чином вищі суспільно-політичні цінності. Із запропонованого вченим списку таких цінностей об'єктом конституційних правовідносин, пов'язаних із перформансом, частіше всього виступають: конституційний лад; демократія, влада народу; державна влада, місцеве самоврядування; права і свободи людини і громадянина; інтереси суспільства і держави; ідеологічна i політична багатоманітність; функції і повноваження держави та органів державної влади й осадових осіб; право і законність [9, с. 129].

Суб'єктів конституційних правовідносин, пов'язаних із перформансом, можна розділити на дві великі групи: автори, якими можуть бути такі суб’єкти конституційних правовідносин, як людина, громадянин, член територіальної громади; та суб’єкти владних повноважень, а саме органи місцевого самоврядування та державні органи.

Відповідно, змістом таких конституційних правовідносин $є$ конституційні права та обов'язки, що виникають у процесі створення перформансу в суб'єктів. Авторами перформансу використовуються конституційні права та свободи, передбачені ч. 1 ст. 34 , ч. 1 ст. 39, ч. 1 ст. $54 \mathrm{KoH}^{-}$ ституції України: право на свободу думки і слова, право на вільне вираження своїх поглядів і переконань, право збиратися 
мирно, і, що найголовніше, реалізується гарантована Конституцією свобода творчості. Як наслідок останньої, на авторів оригінального перформансу має поширюватися конституційна гарантія на захист інтелектуальної власності громадян, їхніх авторських прав, моральних і матеріальних інтересів, що виникають у зв'язку з різними видами інтелектуальної діяльності, передбачена ч. 2 ст. 54 Конституції України [10].

Щодо суб’єктів владних повноважень у відносинах перформансу, то вони набувають право затримати автора, якщо перформанс містить очевидно протиправні елементи, не виходячи за рамки ст. 29 Конституції України; або припинити перформанс в інтересах національної безпеки та громадського порядку з метою запобігання заворушенням чи злочинам, для охорони здоров'я населення або захисту прав і свобод інших людей відповідно до ч. 2 ст. 39 Конституції України [10].

Із вищевказаного можна зробити висновок, що перформанс може виступати інститутом конституційного права.

Таким чином, інститут перформансу в конституційно-правовому ракурсі може реалізовуватись на різних рівнях, проте одними з найпопулярніших $€$ перформанси, пов'язані з місцевим самоврядуванням. Тематично такі «місцеві» перформанси зазвичай носять протестний характер (далі - протестні перформанси). Таким чином, найбільш близькими за метою до перформансів $€$ протестні форми безпосередньої участі членів територіальної громади у здійсненні місцевого самоврядування. Зокрема, мітинги та демонстрації згадуються і в Конституції України [10], і в Законі України «Про місцеве самоврядування в Україні» [11], а страйки, окрім Основного Закону, згадуються ще й у Законі України «Про порядок вирішення колективних трудових спорів (конфліктів)»[12].

Окрім мети, більшість протестних форм громадської діяльності (за винятком страйку [12]) із протестними перформансами об'єднує також відсутність правової дефініції. Навіть більше - перформанси взагалі не згадуються в жодному вітчизняному нормативно-правовому документі. Але якщо мирні «збори, мітинги, походи і демонстрації», а також страйки регулюються статтями 39, 44 Конституції України, то протестні перформанси, як реалізація свободи творчості, мають підпадати під дію ст. 54 Конституції України [10].

Ще одна спільна риса між протестними формами безпосередньої участі членів територіальної громади у здійсненні місцевого самоврядування та протестними перформансами - демонстраційний, необов'язковий характер щодо суб'єктів, на яких спрямовані ці форми. Зазвичай це органи місцевого самоврядування, але це також можуть бути підприємства, установи, організації, діяльність яких пов'язана з вирішенням питань місцевого значення. Наприклад, міська рада може проігнорувати перформанс так само, як і мітинг.

Також спільною рисою між протестними формами безпосередньої участі членів територіальної громади у здійсненні місцевого самоврядування та протестним перформансом $€$ можливість їхньої реалізації аматорами. Так, відповідно до ст. 7 Закону Украіни «Про культуру» «право людини провадити творчу діяльність може реалізовуватися і на професійній, і на аматорській основі». Цією ж статтею передбачено, що втручання у творчий процес і здійснення цензури у творчій діяльності не допускаються [13]. Таким чином, кожен член територіальної громади може стати перформансиситом і такою формою творчості комунікувати із представниками місцевої влади або іншими суб'єктами з питань місцевого самоврядування.

Ураховуючи вищесказане, протестні перформанси можна відносити до протестних форм безпосередньої участі членів територіальної громади у здійсненні місцевого самоврядування.

При цьому в перформансів є унікальні особливості, що робить їх специфічною протестною формою безпосередньої участі членів територіальної громади у здійсненні місцевого самоврядування. Так, інші 
протестні форми зазвичай реалізовуються на вулиці, біля місцезнаходження «адресату» протесту. Натомість мистецька природа перформансу дозволяє доволі ефективно створювати протестні перформанси в різних місцях - як у виставкових залах та орендованих будівлях, так і на вулицях. Прикладом є протестний перформанс «Трава пробиває землю» режисерки Галини Джікаєвої, а також Дена та Яни Гуменних, присвячений російським репресіям у Криму, що проводився в Києві, у «Кримському домі» [8].

Як вже згадувалось вище, протестний перформанс відрізняється від інших протестних форм безпосередньої участі членів територіальної громади у здійсненні місцевого самоврядування наявністю конкретної особи (митця) чи осіб, які нерозривно пов'язані зі своїм твором. Інші ж протестні форми не мають акцентуації на іменах організаторів, а подекуди навіть приховують будь-яку інформації про цих осіб із міркувань безпеки.

Причина цьому доволі таки проста зазвичай протестний перформанс переслідує одразу дві мети. 3 одного боку, перформансист як член територіальної громади прагне вплинути на суспільні явища, пов'язані з місцевим самоврядуванням. 3 іншого боку, перформансист має на меті реалізувати власний потенціал креативності, а іноді ще й набути визнання як митець.

Ще однією суттєвою відмінністю є обов'язок попереджати про проведення мирних зборів, мітингів та демонстрацій органи виконавчої влади чи органи місцевого самоврядування $[10 ; 11]$ (для страйків обов'язково попереджати роботодавця) [12]. Натомість проведення протестних перформансів не потребує попередження будь-кого.

Однак варто зазначити, що деякі протестні перформанси через їхню незвичну реалізацію іноді сприймаються правоохоронними органами як хуліганство або інші протиправні дії. Через це деякі перформансисти добровільно попереджають органи влади. Так, у 2017 році яскравим прикладом українського протестного перформансу було публічне пошкодження нібито неправильно припаркованого автомобіля 3 метою звернути увагу киян до проблеми неправильного паркування [14]. При цьому про акцію була попереджена поліція, адже зі сторони перформанс мав вигляд умисного пошкодження чужого майна, і митці могли бути затримані.

Різною $є$ також мінімальна кількість людей для ефективної реалізації у протестних формах безпосередньої участі членів територіальної громади у здійсненні місцевого самоврядування та перформансах. Так, більшість перформансів виконується однією людиною, зрідка - двома або більше. Серед протестних форм безпосередньої участі членів територіальної громади у здійсненні місцевого самоврядування найближчими до перформансу є голодування та пікети, що також можуть бути реалізовані всього одним членом територіальної громади. Проте ефективність більшості протестних форм безпосередньої участі членів територіальної громади у здійсненні місцевого самоврядування залежить від кількості людей, які беруть у них участь - наприклад, шанси бути почутим є більшими в мітингу, де взяло участь $15 \%$ членів територіальної громади, а не $1 \%$.

Одним із безумовних позитивів протестного перформансу в порівнянні з іншими протестними формами безпосередньої участі членів територіальної громади у здійсненні місцевого самоврядування є набагато краще привернення уваги цільової аудиторії. Головними умовами цього є нетривіальний підхід i, відповідно, привабливість формату перформансу для ЗМI. Причина - в широкому використанні епатажних або навіть шокуючих образів. Так, одним із найбільш яскравих прикладів боротьби з російським режимом став перформанс Петра Павленського у 2013 році. Так, перформансист огорнувся колючим дротом перед будівлею законодавчих зборів у Санкт-Петербурзі, таким чином виступаючи проти «репресивної законодавчої системи, де кожен рух викликає жорстку реакцію закону, що впивається в тіло індивіда» [15]. У результаті вда- 
лося привернути увагу не лише російської влади та громадськості, але й чи не всіх 3MI і світової спільноти.

Як показала практика, ще одним позитивом протестного перформансу $€$ потенційна можливість його реалізації в режимі воєнного стану, на відміну від більшості протестних форм безпосередньої участі. Адже відповідно до ст. 19 Закону України «Про правовий режим воєнного стану» в умовах воєнного стану забороняється проведення страйків, масових зібрань та акцій, а також проведення референдумів [16]. Натомість щодо творчості відсутні автоматичні обмеження, передбачені Законом України «Про правовий режим воєнного стану» [16]. А отже, прийняття рішення про обмеження чи не обмеження свободи творчості (а отже, i протестних перформансів) належить до компетенції Президента України. Наприклад, відповідно до Указу Президента України № 393/2018 від 26 листопада 2018 року «Про введення воєнного стану в Україні» у зв'язку 3 введенням в Україні воєнного стану тимчасово, на період діï правового режиму воєнного стану, з 26 листопада по 26 грудня 2018 р., обмежувалися конституційні права і свободи людини i громадянина, передбачені статтями 30-34, 38, 39, 41-44, 53 Конституціï України» [17]. Як можна помітити, 54-ої статті Конституції немає в переліку статей, які обмежувалися. А тому члени територіальних громад в областях, де був оголошений воєнний стан, могли б використати протестний перформанс як засіб для комунікації з органами місцевого самоврядування, органами державної влади на місцях тощо.

До недоліків протестного перформансу можна віднести необхідність творчого підходу у висловленні ідеї та бажаність попереднього повідомлення засобів масової інформації. Варто також сказати і про ризик можливого несприйняття випадковими очевидцями ідеї протестного перформансу.

Висновки. Протестний перформанс - вид перформансу; разова протестна форма безпосередньої участі чле- нів територіальної громади у здійсненні місцевого самоврядування, чия сутність полягає у вираженні членами територіальної громади публічного протесту за допомогою креативних дій. Протестний перформанс - форма реалізації плеяди конституційних прав та свобод, ключовим із яких є право на свободу творчості.

Протестні перформанси мають ряд значних переваг перед іншими протестними формами безпосередньої участі членів територіальної громади у здійсненні місцевого самоврядування. Серед них можна назвати: доступність для кожного члена територіальної громади, відсутність необхідності великої кількості людей та часу, ефективне привернення уваги до ідеї, закладеної в протесаному перформансі.

Попри це, через необхідність творчої складової частини протестний перформанс в Україні наразі не є популярною формою безпосередньої участі членів територіальної громади у здійсненні місцевого самоврядування. Дуалістична природа інституту протестного перформансу робить його регульованим у перспективі і Законом України «Про культуру», і Законом України «Про місцеве самоврядування в Україні». Так, зазначення права на протестний перформанс як унікальну форму протестної творчості може бути задеклароване в Законі України «Про місцеве самоврядування в Україні». Регулювання протестного перформансу на рівні окремого нормативно-правового не $€$ необхідним, адже регулювання творчості в будь-якій формі зазвичай звужує потенційне різноманіття кінцевих продуктів творців.

За допомогою вдалого протестного перформансу можна досягти комунікації між територіальною громадою та органами місцевого самоврядування, а також між територіальною громадою та місцевими або центральними органами державної влади чи іншими суб'єктами; донести сутність проблеми місцевого значення до територіальної громади, решти населення країни, міжнародної спільноти.

Таким чином, протестний перформанс є перспективною формою безпо- 
середньої участі членів територіальної громади у здійсненні місцевого самоврядування і потребує додаткового дослідження в конституційно-правовому полі.

Ключові слова: перформанс, місцеве самоврядування, територіальна громада, члени териоріальної громади, форми безпосередньої участі у здійсненні місцевого самоврядування.

У статті досліджується протестний перформанс як форма безпосередньої участі иленів територіальної громади у здійсненні місиевого самоврядування. Автором розкрита конституиійно-правова природа перформансу, позитивні та негативні сторони протестного перформансу, його зв'язок із суміжними інститутами; розглянуті перспективи розвитку протестного перформансу у правовому полі.

B cmambe исследуется протестный перформанс как форма непосредственного участия членов территориальной общины в осуществлении местного самоуправления. Автором раскрыта конституиионно-правовая природа перформанса, положительные и отрицательные стороны протестного перформанса, его связь со смежными институтами; рассмотрены перспективы развития протестного перформанса в правовом поле.

The article examines the protest performance as a form of direct participation of the members of local community in the realization of local self-government. The author revealed legal constitutional essence the of performance, the positive and negative aspects of the protest performance, it's connection with related institutes; the prospects of the development of the protest performance in the legal field.

\section{Література}

1. Кривиова Ю.В. Концепт перформанса: действие, действенность и действи- тельность современного искусства. URL : https: / / is.gd/IUDcc1.

2. Roselee Goldberg. Performance: Live Art, 1909 to the present. URL : https:// is.gd/pbRUqG.

3. Сучасна енциилопедія. URL : https: / / goo.gl/sSPKrf.

4. Шість найвідоміших перформансів Марини Абрамович: Cтатmя на «Vogue. ua». URL : https: / / is.gd/aeUB6V.

5. Універсальна науково-популярна енциклопедія. URL: https: //is.gd/3wBYip.

6. Відео з виконаннями перформансів. URL : https: / / ww youtube.com.

7. Eлектронний портал BBC World. URL : https: / / www.bbc.com.

8. У Києві показали перформанс про катування в анексованому Криму : огляд: звіт на «Радіо Свобода». URL : https: // is.gd/sbtpcu.

9. Конституиійне право України : підруч. / До 20-ої річниці Конституцї України та 25-ої річниці незалежності України / В.Л. Федоренко. Київ : Видавництво Лipa-K, 2016. 616 c.

10. Конституція України від 28 червня 1996 р. Відомості Верховної Ради України. № $30 . \mathrm{Cm}$. 141 .

11. Про місцеве самоврядування в Україн $i$ : Закон України від 21 травня 1997 року № 280/97-ВР. Відомості Верховної Ради України. 1997. № 24. Ст. 170.

12. Про порядок вирішення колективних трудових спорів (конфліктів) : Закон України від 03 березня 1998 р. № 137 /98-ВР. Відомості Верховної Ради України. 1998 р. № $34 . \mathrm{Cm}$. 227.

13. Про культуру : Закон України від 14 грудня 2010 р. № 2778-VI. Відомості Верховної Ради України. 2011 р. № 24. Cm. 168.

14. Перформанс в центрі Києва: молодики битами розбили неправильно припарковане авто. URL : https://goo.gl/RjJ6YX.

15.Художник голим загорнувся в колючий дріт перед Законодавчими зборами, протестуючи проти "репресивної законодавчої системи». URL: http:// www.gazeta.spb.ru/1188796-0/.

16. Про правовий режим воєнного стану : Закон України від 12 травня 2015 р. № 389-VIII. Відомості Верховної Ради України. 2015 p. № 28. Cm. 250.

17. Про введення воєнного стану в Україні : Указ Президента України від 26 листопада 2018. № 393/2018. URL : http:// zakon.rada.gov.ua/laws/show/393/2018. 